\title{
Pengaruh Citra Merek Terhadap Keputusan Pembelian Kartu Perdana Tri Pada Warga Kelurahan Pondok Karya Kota Tangerang Selatan
}

\author{
Gita Ramadhani ${ }^{1}$, Sugeng Widodo ${ }^{2 *}$, \\ ${ }^{1}$ Mahasiswa Manajemen, Universitas Pamulang; paksw.uinjkt@gmail.com \\ ${ }^{2}$ Fakultas Ekonomi, Universitas Pamulang; dosen01632@unpam.ac.id*
}

Received 14 Februari 2021| Revised 22 Maret 2021 | Accepted 25 Maret 2021

*Korespondensi Penulis

\begin{abstract}
Abstrak
Penelitian ini bertujuan untuk mengetahui Pengaruh Citra Merek Terhadap Keputusan Pembelian Kartu Perdana Tri Pada Warga Kelurahan Pondok Karya Kota Tangerang Selatan. Metode penelitian yang digunakan yaitu deskriptif kualitatif dengan pemilihan sampel random. Hasil penelitian menunjukan bahwa citra merek berpengaruh positif terhadap keputusan pembelian dengan persamaan regresi $\mathrm{Y}=$ $25,037+2,222 X$. Semakin baik citra merek maka keputusan pembelian akan semakin meningkat dan tingkat hubungan 0,379 yang "rendah" dengan kontribusi pengaruh sebesar 14,4\%. Hasil uji t diperoleh $\mathrm{t}_{\text {hitung }} 11,267>\mathrm{t}_{\text {tabel }} 1,652$ dan signifikansi 0,000 .
\end{abstract}

Kata Kunci : Citra Merek; Keputusan Pembelian.

\begin{abstract}
This study aims to determine the effect of brand image on the decision to purchase Tri starter packs in the residents of Pondok Karya village, South Tangerang city. The research method used is descriptive qualitative with random sample selection. The results showed that brand image had a positive effect on purchasing decisions with the regression equation $Y=25.037+2.222 X$. The better the brand image, the purchase decision will increase and the level of the relationship is 0.379 which is "low" with an influence contribution of $14.4 \%$. The results of the t test obtained tcount 11.267> ttable 1.652 and a significance of 0.000 .
\end{abstract}

Keywords: Brand Image; Purchase Decision.

\section{PENDAHULUAN}

Era globalisasi dan perdagangan bebas, Indonesia harus mempersiapkan diri menghadapi terjadinya perubahan-perubahan besar pada berbagai aspek kehidupan, khususnya aspek ekonomi. Dengan terbukanya pasar global, maka para pengusaha dituntut untuk melakukan pembenahan kinerjanya dalam rangka memenuhi kualitas produk atau jasa di kehendaki oleh pasar (konsumen). Salah satu strategi yang dapat ditempuh adalah strategi pemasaran.
Setiap perusahaan akan berusaha menyusun strategi pemasaran yang dapat menjangkau pasar sasarannya dengan seefektif mungkin. Setiap strategi pasti dilengkapi dengan alat-alat pemasaran yang dianggap paling tepat bagi perusahaan. Alat-alat tersebut disebut sebagai bauran pemasaran. Salah satu strategi bauran pemasaran adalah strategi produk. Strategi produk yang dapat dilakukan oleh perusahaan salah satunya adalah dengan menciptakan brand. Menurut Buchari Alma (2012:96), "keputusan pembelian adalah suatu keputusan konsumen yang di pengaruhi oleh ekonomi keuangan, teknologi, politik, budaya, 
produk, harga, lokasi, promosi, physical evidence, people dan proses". Salah satu industri yang tumbuh pesat sampai saat ini adalah industry telekomunikasi., perkembangan ditunjang dengan bertambah kuatnya jaringan dengan kecepatan $4 \mathrm{G}$, dan kebutuhan setiap orang untuk mengakses internet dengan cepat. Peluang tersebut dimanfaatkan oleh provider telekomunikasi yang ada di Indonesia. Berikut adalah data penjualan kartu perdana tri :

Tabel 1. Data Penjualan

Kartu Perdana Tri'3 2017-2018

\begin{tabular}{lcc}
\hline \multirow{2}{*}{ Bulan } & \multicolumn{2}{c}{ Jumlah Penjualan } \\
\cline { 2 - 3 } Januari & $\mathbf{2 0 1 7}$ & $\mathbf{2 0 1 8}$ \\
\hline Februari & 3.950 .781 & 2.145 .675 \\
\hline Maret & 3.768 .890 & 2.297 .985 \\
\hline April & 4.160 .877 & 1.176 .908 \\
\hline Mei & 4.490 .789 & 2.190 .974 \\
\hline Juni & 5.728 .871 & 2.287 .936 \\
\hline Juli & 5.978 .890 & 3.445 .789 \\
\hline Agustus & 5.989 .856 & 3.120 .087 \\
\hline September & 5.856 .900 & 4.540 .304 \\
\hline Oktober & 6.950 .820 & 3.208 .967 \\
\hline November & 6.967 .856 & 2.300 .987 \\
\hline Desember & 5.965 .890 & 2.103 .406 \\
\hline
\end{tabular}

Sumber : https://amp.kompas.com

Pada tahun 2017 penjualan kartu Tri'3 sebanyak 63,8 juta. Sedangkan di tahun 2018 mengalami penurunan menjadi 30 juta, di sebabkan oleh adanya registrasi ulang yang diadakan oleh pemerintah.

Menurut Kotler dan Keller (2012:248) "Brand Image describes the extrincis properties of the product or service, including the ways in which the brand attempts to meet customers psychological or social needs". Citra merek menggambarkan sifat ekstrinsik dari suatu produk atau jasa termasuk cara dimana merek berusaha memenuhi kebutuhan psikologis atau social pelanggan. Kurangnya keunikan dan rendahnya keunggulan dari kartu perdana Tri'3 daripada kartu perdana lain membuat konsumen lebih memilih kartu perdana lain yang memiliki keunggulan seperti kecepatan jaringannya.

Produk industri telekomunikasi sangat kompetitif dalam bentuk kecepatan jaringan, harga, merek dan kekuatan jaringan. Merekmerek provaider yang di pasarkan di Indonesia sekarang ini seperti Telkomsel, Indosat, XL, Axis, Smartfren dan Three yang banyak diminati oleh masyarakat Indonesia. Setiap merek produk menawarkan pelayanan tersendiri untuk pelanggannya, berupa service, promo, kemudahan transaksi, sampai penetapan harga yang cukup bersaing sesuai dengan jenis dan segmen pasarnya. Survey Top Brand juga melakukan survey pada Kartu Perdana Three seperti yang terlihat dalam tabel berikut ini :

Tabel 2. Top Brand Index Kategori Kartu Perdana 2017-2018

\begin{tabular}{lcc}
\multirow{2}{*}{ Merek } & \multicolumn{2}{c}{ Top Brand Index $(\mathbf{T B I})$} \\
\cline { 2 - 3 } & $\mathbf{2 0 1 7}$ & $\mathbf{2 0 1 8}$ \\
\hline Telkomsel & $35,5 \%$ & $34,6 \%$ \\
\hline IM3 & $15,4 \%$ & $13,6 \%$ \\
\hline XL & $14,8 \%$ & $13,4 \%$ \\
\hline Tri'3 & $11,3 \%$ & $11,4 \%$ \\
\hline Smartfren & $10,4 \%$ & $8,6 \%$ \\
\hline
\end{tabular}

Sumber : www.topbrand-award.com

Berdasarkan tabel 2 terlihat bahwa Kartu Perdana Telkomsel, IM3, dan XL, sebagai Kartu Perdana yang mendominasi penjualan Kartu Perdana di Indonesia. Kartu Perdana Tri'3 menempati urutan ke 4 di tahun 20172018.

Tabel 3. Kecepatan Jaringan Kartu Perdana 2018

\begin{tabular}{lcl}
\hline Kartu perdana & \multicolumn{2}{c}{ Kekuatan Jaringan } \\
\cline { 2 - 3 } & Download & Upload \\
\hline Telkomsel & $10,64 \mathrm{Mbps}$ & 7,91 Mbps \\
\hline Smartfren & $9,60 \mathrm{Mbps}$ & $2,14 \mathrm{Mbps}$ \\
\hline XL Axiata & $4,35 \mathrm{Mbps}$ & $2,95 \mathrm{Mbps}$ \\
\hline $\begin{array}{l}\text { Indosat } \\
\text { Ooredoo }\end{array}$ & $2,68 \mathrm{Mbps}$ & $2,15 \mathrm{Mbps}$ \\
\hline Hutchison 3 & $2,96 \mathrm{Mbps}$ & $2,11 \mathrm{Mbps}$ \\
\hline
\end{tabular}

Sumber : kompas.com

Pada kekuatan jaringan download di tahun 2018 kartu perdana Three menempati posisi ke 5 dengan kekuatan 2,96 Mbps dan untuk kekuatan upload menempati posisi ke 5 dengan kekuatan 2,11 Mbps. Konsumen saat ini juga sangat kritis dalam memilih suatu produk, sampai pada keputusan untuk membeli produk tersebut. Seperti diketahui bersama bahwa tawaran produk saat ini sangatlah beragam dan banyak. Alternatif pilihan yang semakin banyak memudahkan konsumen untuk menentukan pilihan sesuai dengan selera, kebutuhan dan kemampuan ekonominya.

Keputusan untuk membeli suatu produk sangat dipengaruhi oleh penilaian akan kualitas produk tersebut. Tuntutan permintaan akan 
sebuah produk barang yang akan semakin berkualitas membuat perusahaan bergerak diberbagai bidang berlomba-lomba meningkatkan kualitas produk yang mereka miliki demi mempertahankan brand image (citra merek) produk yang mereka miliki.

PT Hutchison CP Telecommunications (HCPT) atau yang dikenal dengan merek Tri, berubah nama menjadi PT Hutchison 3 Indonesia. Unit bisnis Hutchison di Indonesia ini termasuk jaringan operator kecil. Saat ini Hutchison 3 Indonesia berada di posisi keempat sebagai operator terbesar berdasarkan jumlah pelanggan. Sehingga membentuk suatu produk yang berkualitas, bukan hanya dari segi pelayanan tetapi secara keseluruhan. Minat masyarakat dalam menggunakan kartu perdana Tri'3 inilah yang memacu para penyedia jasa telekomunikasi lainnya untuk berlomba-lomba bersaing untuk menghasilkan produk yang berkualitas diminati masyarakat. Hal ini menjadi kebijaksanaan pemasaran perusahaan dengan harapan produk yang dapat dipasarkan dapat menembus pasar, serta meraih pangsa pasar yang luas. Berikut adalah data pelanggan kartu perdana dari tahun 2017 sampai bulan April 2018:

Tabel 4. Data Pelanggan Kartu Perdana

\begin{tabular}{cc}
\hline Kartu perdana & Periode \\
\cline { 2 - 2 } & s/d April 2018 \\
\hline Telkomsel & 150 juta \\
\hline Smartfren & 45 juta \\
\hline XL Axiata & 34 juta \\
\hline Indosat Ooredoo & 17 juta \\
\hline Hutchison 3 & 7 \\
\hline
\end{tabular}

Sumber : kontan.co.id

Dari tabel 4 kartu perdana Tri'3 menempati urutan ke 4 ditahun 2018. Tetapi kartu perdana Tri'3 pun mengalami banyak kendala dalam pemasaran, salah satunya adalah dalam penjualan. Daya beli konsumen yang bervariatif meng-akibatkan tingkat penjualan kartu perdana Tri'3 menjadi fluktuatif, sehingga keputusan untuk membeli kartu perdana menjadi menurun.

Penelitian ini bertujuan untuk menganalisis Pengaruh Citra Merek Terhadap Keputusan Pembelian Kartu Perdana Tri Pada Warga Kelurahan Pondok Karya Kota Tangerang Selatan.

Manajemen, menurut Wijayanto (2012:10) merupakan ilmu dan seni. Manajemen sebagai ilmu disusun melalui proses pengkajian yang panjang oleh para ilmuwan bidang manajemen dengan pendekatan ilmiah. Dalam aplikasinya, manajemen merupakan seni, yaitu seni mengelola sumber daya yang dimiliki untuk mencapai tujuan yang ingin diraih.

Citra adalah perasaan, gambaran diri publik terhadap perusahaan, organisasi atau lembaga; kesan yang dengan sengaja diciptakan dari suatu objek, orang atau organisasi, ( Ardianto, 2013: 62)

Merek, menurut Alma (2013:147) adalah suatu tanda atau symbol yang memberikan identitas suatu barang atau jasa tertentu yang dapat berupa kata-kata, gambar atau kombinasi keduanya.

Citra Merek, Kotler dan Keller (2016:345), mendefinisikan "citra merek sebagai sekumpulan persepsi dan kepercayaan yang dimiliki oleh pelanggan terhadap suatu brand yang direfleksikan melalui asosiasiasosiasi yang ada dalam ingatan pelanggan".

\section{Kerangka Berfikir Penelitian}

\begin{tabular}{|c|c|}
\hline Citra Merek (X) & Keputusan Pembelian (Y) \\
\hline $\begin{aligned} & \text { Indikator: } \\
& \text { - } \text { Citra pembuat } \\
& \text { (Corporate Image) } \\
& \text { - } \text { Citra Pemakai (User } \\
& \text { Image) } \\
& \text { - } \text { Citra Produk (Product } \\
& \text { Image) }\end{aligned}$ & $\begin{array}{l}\text { Indikator: } \\
\text { - Pengenalan masalah } \\
\text { - Pencarian informasi } \\
\text { - Evaluasi alternative } \\
\text { - Keputusan pembelian } \\
\text { - Perilaku pasca pembelian }\end{array}$ \\
\hline $\begin{array}{l}\text { Sumber: David Aaker dan Alexander } \\
\text { L Biel (dalam Thambrin 2010:61) }\end{array}$ & Sumber : Kotler dan Keller (2017:577) \\
\hline
\end{tabular}




\section{Gambar 1. Kerangka Berpikir}

\section{METODE}

Jenis penelitian ini adalah asosiatif, menurut Sugiyono (2017:44) yaitu "Penelitian yang bertujuan untuk mengetahui pengaruh atau hubungan antara dua variabel atau lebih". Dengan demikian penelitian asosiatif ini dapat dibangun suatu teori yang berfungsi untuk menjelaskan, meramalkan dan mengontrol suatu gejala. Penelitian ini merupakan studi empiris yang bertujuan untuk menguji pengaruh citra merek terhadap keputusan pembelian Kartu Perdana Tri di Kelurahan Pondok Karya Kota Tangerang Selatan. Total populasi sebesar 4.107 orang dengan menyederhanakan menggunakan rumus slovin untuk mencari sampel, maka di dapatkan hasil 97,62 dibulatkan menjadi sebesar 98 dan untuk sampel diambil 98 responden.

\section{HASIL DAN PEMBAHASAN}

\section{Uji Validitas}

Untuk menguji validitas instrumen, peneliti menggunakan analisis dengan SPSS versi 22. Menurut Sugiyono (2013) syarat minimum untuk memenuhi syarat $\mathrm{r}=0,196 \mathrm{r}$ hitung > 0,196 dinyatakan "Valid" dan jika $r$ hitung < 0,196 maka dinyatakan "Tidak Valid".

Tabel 5. Hasil Uji Validitas Citra Merek (X)

\begin{tabular}{cccc}
\hline \multicolumn{4}{c}{ Citra Merek (X) } \\
\hline No & R hitung & R tabel & Ket \\
\hline 1 & 0,627 & 0,196 & Valid \\
\hline 2 & 0,585 & 0,196 & Valid \\
\hline 3 & 0,219 & 0,196 & Valid \\
\hline 4 & 0,662 & 0,196 & Valid \\
\hline 5 & 0,556 & 0,196 & Valid \\
\hline 6 & 0,589 & 0,196 & Valid \\
\hline 7 & 0,602 & 0,196 & Valid \\
\hline 8 & 0,408 & 0,196 & Valid \\
\hline
\end{tabular}

Tabel 6. Hasil Uji Validitas Keputusan Pembelian (Y) Keputusan Pembelian (Y)

\begin{tabular}{cccc}
\hline No & R hitung & R tabel & Ket \\
\hline 1 & 0,646 & 0,196 & Valid \\
\hline 2 & 0,617 & 0,196 & Valid \\
\hline 3 & 0,574 & 0,196 & Valid \\
\hline 4 & 0,582 & 0,196 & Valid \\
\hline 5 & 0,632 & 0,196 & Valid \\
\hline 6 & 0,617 & 0,196 & Valid \\
\hline 7 & 0,648 & 0,196 & Valid \\
\hline 8 & 0,648 & 0,196 & Valid \\
\hline 9 & 0,632 & 0,196 & Valid \\
\hline 10 & 0,647 & 0,196 & Valid \\
\hline
\end{tabular}

Sumber: Output SPSS versi 22

Dari tabel di atas maka dapat disimpulkan bahwa semua variabel dinyatakan valid karena $r$ hitung $>r$ tabel $(0,196)$.

\section{Uji Reliabilitas}

Tabel 7. Uji Reliabilitas Variabel X dan Y

\begin{tabular}{cllcc}
\hline No & Variabel & $\begin{array}{l}\text { Cronbach's } \\
\text { Alpha }\end{array}$ & $\begin{array}{c}\mathrm{r} \\
\text { tabel }\end{array}$ & Ket. \\
\hline 1 & $\begin{array}{l}\text { Citra } \\
\text { Merek (X) }\end{array}$ & 0,663 & 0,196 & Reliabel \\
\hline 2 & $\begin{array}{l}\text { Keputusan } \\
\text { Pembelian } \\
(Y)\end{array}$ & 0,824 & 0,196 & Reliabel \\
\hline
\end{tabular}

Sumber : Data yang diolah (2020)

Dari tabel dapat dilihat bahwa variabel Citra Merek sebesar (X) 0,663 dan Keputusan Pembelian (Y) sebesar 0,824. Dengan demikian dapat disimpulkan bahwa dalam kuisoner dinyatakan Reliabel, hal ini dibuktikan dengan $r$ alpha $>r$ tabel.

\section{Uji Regresi Linier Sederhana}

Regresi linier sederhana didasarkan pada hubungan fungsional maupun kausal satu variabel independent dengan satu variabel dependen. Uji regresi ini dimaksudkan untuk mengetahui seberapa besar pengaruh citra merek terhadap keputusan pembelian. Sebelum dilakukan uji regresi, maka terlebih dahulu akan disajikan hasil olahan data regresi dengan menggunakan program SPSS versi 22 yang dapat dilihat pada tabel berikut ini: 
Tabel 8.Uji Regresi Linier Sederhana

Coefficients $^{\text {a }}$

\begin{tabular}{|c|c|c|c|c|c|c|}
\hline & \multirow[b]{2}{*}{ Model } & \multicolumn{2}{|c|}{$\begin{array}{c}\text { Unstandardized } \\
\text { Coefficients }\end{array}$} & \multirow{2}{*}{$\begin{array}{c}\begin{array}{c}\text { Standardized } \\
\text { Coefficients }\end{array} \\
\text { Beta }\end{array}$} & \multirow[b]{2}{*}{$\mathrm{T}$} & \multirow[b]{2}{*}{ Sig. } \\
\hline & & $\bar{B}$ & Std. Error & & & \\
\hline \multirow[t]{2}{*}{1} & (Constant) & 25.037 & 2.222 & & 11.267 & .000 \\
\hline & Citra Merek & 0.587 & .102 & .379 & 5.761 & .000 \\
\hline
\end{tabular}

Dependent Variable: Keputusan Pembelian

Sumber : Output SPSS 22 (2020)

Berdasarkan hasil tabel di atas, maka diperoleh persamaan regresi $\mathbf{Y}=\mathbf{2 5 , 0 3 7}+$ $\mathbf{2 , 2 2 2 X}$, interpretasinya adalah konstanta sebesar 25,037 menyatakan bahwa jika variabel Citra Merek bernilai nol, maka keputusan pembelian sudah bernilai 25,037. Koefisien regresi sebesar 2,222 pada variabel Citra Merek, makan akan menyebabkan kenaikan sebesar 2,222 satuan pada keputusan pembelian.

\section{Uji Hipotesis (Uji-t)}

Uji hipotesis dilakukan untuk mengetahui pengaruh kedua variabel tersebut. Hasil uji $\mathrm{t}$ seperti ditunjukkan pada tabel berikut:

Tabel 9. Hasil Uji t

Coefficients $^{\text {a }}$

\begin{tabular}{|c|c|c|c|c|c|c|}
\hline & \multirow[b]{2}{*}{ Model } & \multicolumn{2}{|c|}{$\begin{array}{l}\text { Unstandardized } \\
\text { Coefficients }\end{array}$} & \multirow{2}{*}{$\begin{array}{c}\text { Standardized } \\
\text { Coefficients } \\
\text { Beta } \\
\end{array}$} & \multirow[b]{2}{*}{$\mathrm{T}$} & \multirow[b]{2}{*}{ Sig. } \\
\hline & & $\bar{B}$ & Std. Error & & & \\
\hline \multirow[t]{2}{*}{1} & (Constant) & 25.037 & 2.222 & & 11.267 & .000 \\
\hline & Citra Merek & 0.587 & .102 & .379 & 5.761 & .000 \\
\hline
\end{tabular}

Dependent Variable: Keputusan Pembelian

Sumber : Output SPSS 22 (2020)

Berdasarkan hasil di atas, diperoleh nilai $\mathrm{t}$ hitung $>\mathrm{t}$ tabel $(11,267>1,652)$ dengan nilai signifikan $0,000<0,1$ artinya $\mathrm{Ho}_{0}$ ditolak dan $\mathrm{Ha}$ diterima. Berarti terdapat pengaruh positif dan signifikan antara Citra Merek (X) terhadap Keputusan Pembelian (Y).

\section{SIMPULAN}

Berdasarkan hasil Analisa dapat disimpulkan:

Citra Merek berpengaruh signifikan terhadap keputusan pembelian Kartu Perdana Tri Pada Warga Kelurahan Pondok Karya Kota Tangerang Selatan, dengan hasil uji t diperoleh nilai $\mathrm{t}$ hitung $>\mathrm{t}$ tabel $(11,267>1,652)$ dan nilai signifikan $0,000<0,1$, maka dapat dikatakan signifikan.

Perlu adanya penelitian lanjutan yang dapat mengungkapkan faktor-faktor lain yang mempengaruhi keputusan pemelian kartu perdana Tri, selain citra merek.

\section{DAFTAR PUSTAKA}

Abdullah, T \& Francis, T. (2012). Manajemen Pemasaran. Depok: Raja Grafindo Persada, Jakarta.

Achmad, S. (2010). Marketing In Business. Penerbit: Mitra Wawancara Media.

Alma, B. (2013) "Manajemen Pemasaran Dan Pemasaran Jasa". Alfabeta. Bandung.

Alma, B. (2013). Manajemen Pemasaran dan Pemasaran Jasa, Penerbit: Alfabeta, Bandung.

Assauri, S. (2014). Manajemen Pemasaran. Edisi revisi, penerbit: Rajawali Pers. Jakarta.

Fandy, T. (2012). Strategi Pemasaran, Penerbit Andi, Yogyakarta.

Hasibuan, M (2016), Manajemen Sumber Daya Manusia. Edisi Revisi. Penerbit PT Bumi Aksara, Jakarta.

Kotler, P \& Amstrong,G.(2012). Prinsipprinsip Pemasaran. Edisi 13. Jilid 1. Erlangga. Jakarta. 
Erlangga. R, Stephen, P \& Coulter,M. (2015). Manajemen, diterjemahkan oleh Bob

Sabran, Wibi Hardani. Erlangga, Jakarta.

Sangadji, E \& Sopiah. (2013). Perilaku Konsumen. C.V andi Offset.

Tjiptono, F \& Chandra,G (2015). Pemasaran strategic. Penerbit: Andi, Yogyakarta.

Altje, Sumpu, \& Novita. (2018). Analisis Pengaruh Citra Merek dan Kualitas Produk Terhadap Keputusan Pembelian Smartphone Samsung (Studi Pada Mahasiswa Universitas Samratulangi Manado Angkatan 2016 ).

Listyorini, S,. Seno, A,. \& Ratnasari, M. (2014). Pengaruh Citra Merek dan Kualitas Produk Terhadap Keputusan Pembelian Blackbery (Studi Kasus pada Mahasiswa S1 FISIP Universitas Diponegoro Semarang).

Oktarini, R. (2020). Pengaruh Harga dan Citra Merek Terhadap Keputusan Pembelian Handphone Merek Xiaomi di Kota Tangerang.

Praastiningtyas, T. R. (2016). Pengaruh Citra Merek, Kualitas Produk, dan Harga Terhadap Keputusan Pembelian Kartu Seluler.

Sari, P. H. (2016). Pengaruh Citra Merek, Fitur, dan Persepsi Harga Terhadap Keputusan Pembelian (Studi Pada Konsumen SmartphoneXiaomi dI DIY). Soepeno, D., Tumbuan, W. J. F. A., \& Armando, Y. (2015). Pengaruh Citra Merek, Fitur dan Harga Terhadap Keputusan Pembelian Handphone Samsung (Studi Pada Mahasiswa FEB Unsrat Manado).

Syahputera,. Gifani, A. (2017). Pengaruh Citra Merek Terhadap Keputusan Pembelian Produk Smartphone Oppo Pada Mahasiswa Universitas Telkom.

Widodo, H., Hidayat, W., \& Alana, A. (2013). Pengaruh Citra Merek, Desain, dan Fitur Produk terhadap Keputusan Pembelian Handphone Nokia (Studi Kasus pada Mahasiswa Universitas Diponegoro). 